\title{
Western Siberia, a Review of Holocene Climatic Changes
}

\author{
Tatiana A. Blyakharchuk* \\ Institute of Monitoring of Climatic and Ecological Systems SB RAS \\ 10/3 Akademichesky, Tomsk, 634055 Russia $^{1}$
}

Received 3.03.2009, received in revised form 10.03.2009, accepted 17.03.2009

This article generalizes published palaeoecological and palaeoclimatic data based on pollen and other proxy data for Holocene of Western Siberia and describes the most significant palaeoreconstructions and hypothesis in explanation of past climatic changes in Western Siberia, although it does not pretend on overall review of all palaeopalynological data available for this region.

Key words: Siberia, pollen analyses, palaeovegetation, palaeoclimate.

\section{Introduction}

Pollen analyses of peat and lake sediments accompanied by radiocarbon dates and, were possible, by macrofossil data are strong instrument for study of past changes of vegetation and landscapes. Taking into account a close connection of types of vegetation with climatic conditions palaeopalynological data can be used for qualitative and quantitative reconstructions of changes of palaeoclimate, which allow to observe long time climatic oscillations in the past long before instrumental era of observations of climatic parameters. To the end of 20 -th century quite a lot of pollen diagrams supplied by radiocarbon dates were published for territory of WesternSiberia.Generalizing paleopalynological data, macrofossil and some other proxy data (macrofossil data and information about change of lake levels) researchers performed reconstructions of palaeoclimates of Western Sibiria in the Late Glacial and the Holocene time. Each generalized palaeoclimatic curve is based on well proved detailed research of one or another natural archive of proxy data. Comparing of these curves allocated on the same time scale can provide information about local and regional fluctuations of climate, among which fluctuations which are similar in different curves and proxies reflect more global and regional events in climatic changes and those presented only in individual curves reflect change of local climates.

\section{Short geographic description of the area}

The complicated character of Holocene climatic changes in Western Siberia is a result of the continental position of this extensive low plain (52-72 degrees $\mathrm{N}, 60-90$ degrees $\mathrm{E}$ ). The climate of Western Siberia is temperatecontinental and is controlled by the alternation of Atlantic storms and Asiatic anticyclones, with the influence of the Arctic air mass from the north and the subtropical air mass from Central Asia (Trifonova, 1982). Clear latitudinal vegetation zones in Western Siberia range from

\footnotetext{
* Corresponding author E-mail address: tarun5@rambler.ru (C) Siberian Federal University. All rights reserved
} 
tundra in the north to boreal forest (taiga) to birch forests and steppe in the south, with transitional subzones at ecotones.

\section{Patterns of the Holocene climatic changes in Western Siberia and hypothesis connected with them}

On the basis of available palynological data from the whole of Western Siberia, plantmacrofossil investigations in the Yenisey River region, and investigations of lake-level changes in the forest-steppe and steppe zones, the palaeoclimatic reconstructions were performed for the entire Holocene by different researches during second half of 20-th centuary. With use of different methods of qualitative and quantitative reconstructions of paleoclimate the results have been presented as palaeoclimatic curves (Fig. 1.) In available publications each researcher presented well established palaeoreconstructions of past climates, but in many cases there were not clear contradictions in results of different researcher. The aim of this article is to compare different palaeoclimatic curves and to analyze possible reasons of similarities or dissimilarities of them. One of the first qualitative palaeoclimatic curve was constructed by A.V. Shnytnikov on the base of available historical data for Euroasia and Northern America (Fig. 1. C) (Shnytnikov, 1951). This curve reflects mostly fluctuations of humidity of climate. Zonal method of palaeoclimatic reconstructions based on close connection of different types of vegetation (and their pollen specters) with climatic zones and on special meaning attributed to indicator types of pollen was used by S. S. Savina and N.A. Khotinskiy (1984) as well as by V.S. Volkova and T.P. Levina (1985) for paleoreconstruction of average annual temperatures and annual amount of atmospheric plecipitations (Fig. 1, A, B).

Information-statistic method of Klimanov based on pollen taxa of tree species and common composition of pollen specters in each pollen sample from palynological diagrams (Klimanov, 1976; Blyakharchuk, 1989; Glebov et al.., 1996; Volkova and Klimanov, 1988) produced another type of palaeoclimatic curves an examples of which for south-eastern part of Western Siberia is presented in Fig. 1. F, G. (Blyakharchuk, 1989). One can mention more complicated appearance of these palaeoclimatic curves, which can be result of influence of more uncertainties involved in mathematic analyses of pollen data. Similar approach to pollen data, but with use of another mathematical method such as discriminant analyses and equations of regression was used by G. Yu. Zubareva (1987) for pollen data located slightly to the east from Western Siberia in Minusinskaya steppe (Fig. 1, E). There is evident correlation between curves of precipitations constructed by these two methods for two sites located in forest-steppe zone (Fig. 1, E and F). This is evidence both of similar mathematical approach to pollen data and of regional (or global) nature of the reflected climatic changes. As additional reassurance of the last conclusion we can present palaeoecological curves constructed by method of ecological scales (Blyakharchuk, 1989) on the base of macrofossil composition of peat from mire located in floodplain of Ob' River in subtaiga zone of Western Siberia (Fig. 1, H), which demonstrates similar wet interval 2000 years ago, dry interval between 1 and 2 thousand years ago and dry interval between 2 and 3 thousand years ago. If similar climatic events have been fixed by few independent methods, it increases considerably their probability.

Among other methods it is need to mention mathematical method of analogues (Burashnikova et al.., 1982) and method of ecology-geographic analyses of carpological materials (Koshkarova, 1989). Very interesting palaeoclimatic curves were constructed by L.A. Orlova, (Orlova, 1986; 

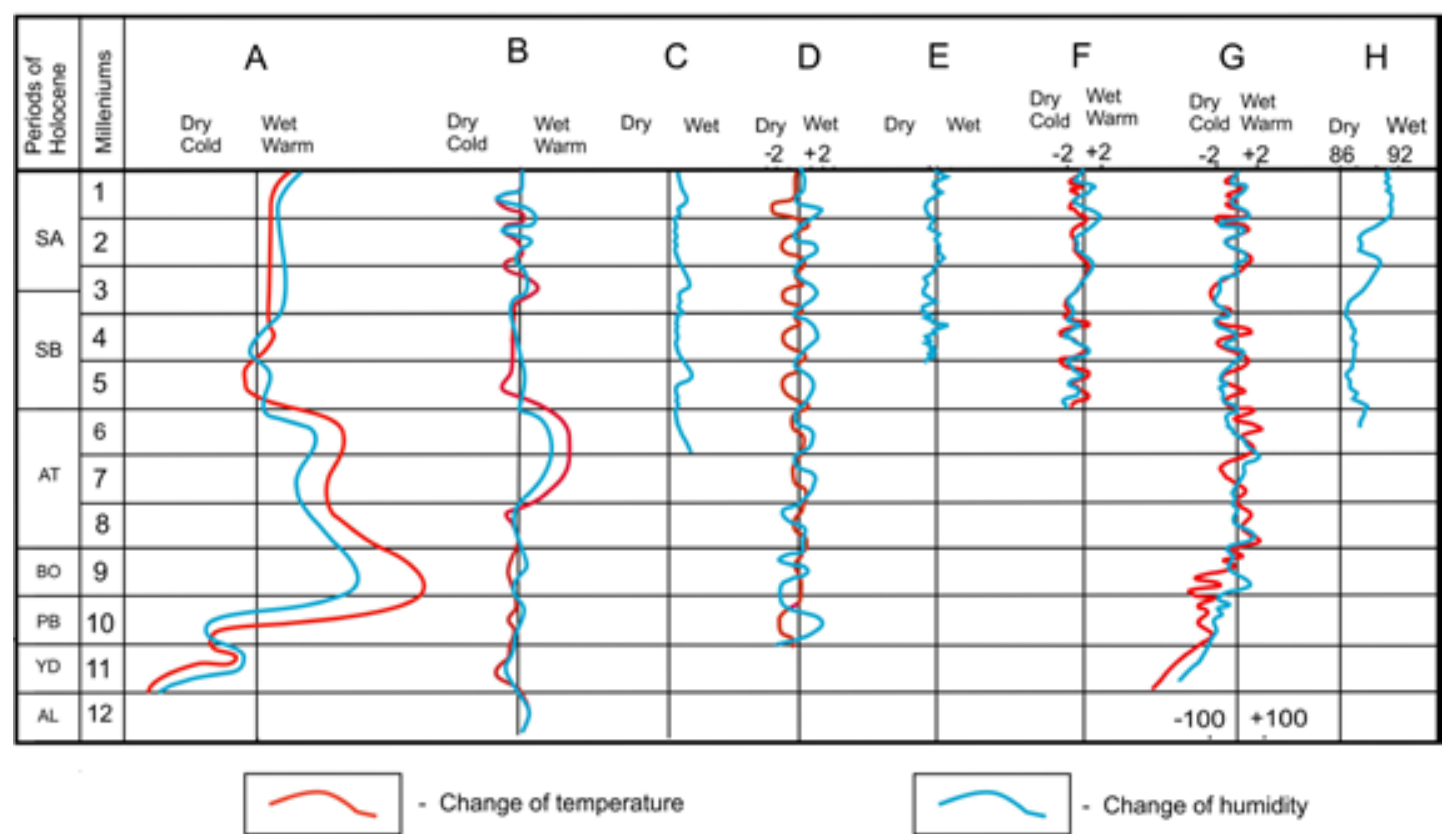

Fig. 1. Correlation on one time scale of palaeoclimatic curves for Holecene of Western Siberia constructed with use of different qualitative and quantitative methods based on pollen data, macrofossil data and historical data and: where: A - palaeoclimatic curves constructed by N.A.Khotinskiy (1977) on the base of pollen data. B - palaeoclimatic curves constructed by V.S.Volkova and T.P. Levina (1985) based on the pollen data. C - curve of humidity of climate constructed by A.V.Shnytnikov (1951) on the base of historical data for all northern hemisphere. D - palaeoclimatic curves constructed by T.P.Levina and L.A.Orlova (1993) for south of Western Siberia on the base of pollen data (in deviations from modern level). $\mathbf{E}$ - palaeoclimatic curve of annual amount of precipitation constructed by G. Yu. Zubareva (1987) for Minusinskaya steppe with use of discriminant analyses of pollen data. F and $\mathbf{G}$ - palaeoclimatic curves of average annual temperatures and annual amount of precipotation (in deviations from modern level) constructed by T.A.Blyakharchuk (1989) with use of information-statistic method of Klimanov (1976) on the base of pollen data from south-eastern Siberia, were $\mathbf{F}$ - reconstructions for subtaiga zone, and $\mathbf{G}$ - reconstructions for middle and southern taiga zone. $\mathbf{H}$ - curve of change of moisture on the mire in subtaiga zone constructed by T.A. Blyakharchuk (1989) with use of method of ecological scales of moisture of soils on the base of macrofossil composition of peat deposits (1989) (in steps of ecological scale)

Levina and Orlova, 1993) for forest-steppe zone of Western Siberia (Fig. 1, D) on the base of palaeopalynological and radiocarbon data in which special attention have been paid to such pollen types as trees pollen, pollen of Artemisia, Chenopodiaceae and Poaceae in combination with Betula nana pollen. As a limitation of most palaeoreconstructions one can mention the use of rather scattered palynological data for so vast and diverse an area as Western Siberia and insufficient attention to complex local conditions in affecting pollen spectra.

According to most published data the Holocene climatic changes in Western Siberia consisted of alternation of cool and warm periods in combination with changes in humidity and continentality. These climatic oscillations were superimposed on the main trend of gradual warming in the first half of the Holocene and gradual cooling in the second half. This picture is in accordance with hypothesis of maximum of summer insolation, which took place at the beginning of Holocene at about 10000 years ago. At the same time the climate of the Holocene fluctuated between stages of relative stability and periods of rapid changes (Khotinskiy, 1984). The warmest climatic conditions of the Holocene, so called climatic optimum, took place in the middle Holocene at about 5500-6000 yr BP in central part of Western Siberia according to 
V.S.Volkova and T.P. Levina (1983) (Fig. 1, B). According to N.A. Khotinskiy (1984) the model of Holocene climatic changes in Western Siberia differs from that of Europe by the stronger Boreal thermal maximum, which was accompanied by an increase in precipitation (Fig. 1, A). Summarizing this information V.S.Volkova and V.A. Klimanov (1988) concluded, that in Western Siberia Boreal (BO) and Subboreal (SB) thermal maxima took place at 8500 and $3500 \mathrm{yr}$ BP. At the same time one can mention, that the Boreal climatic maximum was more clear expressed on the north of Western Siberia, but in the middle part of Western Siberia only Atlantic (AT) climatic optimum was pronounced, and in the south in forest-steppe zone the picture was not so contrast, but more complicated with numerous displacements of southern boundary of forest zone to the north and to the south. This can be result of different parameters used for determination of conception of «Holocene optimum». In the north Holocene optimum was fixed by northward shifting of forest zone caused by warming of climate. In the middle part of Western Siberia (in taiga zone) the Holocene optimum was marked by maximal spreading of Abies sibirica the most thermophylous and methophyllous tree species among Siberian tree species (Shumilova, 1962), that was connected with warming and increased humidity of climate. In the south the limiting factor for spreading of forests is humidity of climate, which fluctuated in Western Siberia during Holocene many times (Fig. 1, D). Reflecting of these situation we can observe in the picture of correlation of different palaeoclimatic curves for Western Siberia (Fig. 1). The next important peculiarity of West Siberian climate was the cooling and increase of continentality in the second half of the Holocene. It is so-called Siberian continental type of past climatic change. These fluctuations were caused by the rearrangement of atmospheric circulation above northern Eurasia and by change in the Arctic ice (Khotinskiy, 1984).

Other researchers (Levina and Orlova, 1993) in reconstructing the development of vegetation and climate in the south of Western Siberia, distinguished 10 uniform cycles with a duration of 1000 years, each of which includes 4 intervals of 250-300 years. Each cold period continues for 500-600 years; with the same duration for each warm period (Fig. 1, D). The cycle started by warm and dry interval followed by warm and wet interval, then by cold and wet and then by cold and dry intervals. The dry periods were more clearly expressed in the first half of the Holocene and the wet periods in the second half after $6650 \mathrm{yr}$ BP. Finer fluctuations of climate were superimposed on these cycles.

According to point of view of V.A. Klimanov and A.A. Sirin (1997) the Holocene climatic oscillations in Western Siberia were cyclic, but have a quasi periodic character. Under these conditions in the north the precipitation increased during warm periods and decreased during cold periods. In the south the picture was opposite, and in the middle latitudes the maxima of precipitation occurred between extremes of warming and cooling. This hypothesis finds conformation in correlation of different types of palaeoclimatic curves (Figire 1). Southern type of climatic oscillations is clear expressed in climatic curves constructed by T.P. Levina and L.A. Orlova (1993) for forest-steppe zone of Western Siberia. Climatic curves constructed by method of Klimanow for forest zone of south-eastern part of Western Siberia are more close to northern type of climatic fluctuations (Fig. 1. F, G). But at some time intervals, such as in the middle Atlantic period (AT-7) and in Boreal period (BO-9) it changed to southern type of fluctuations, that is clear evidence of shifting of southern boundary of forest zone in Western Siberia during these time intervals. 
During the Holocene in Western Siberia the main changes in climate and landscape as described by different methods were probably caused by global factors. Bellow is generalized picture of climatic and landscape changes in Western Siberia during the Holocene.

\section{Compilation of palaeoclimatic reconstructions according to periods of Holocene}

Preboreal period (PB). If to accept chronostratigraphic division of the Holocene according to J. Mangerud et al., (1974), then the first Holocene warming in Western Siberia took place in the first half of the Preboreal (PB). From this time severe continental climatic conditions with widespread permafrost changed to a milder climate, tundra-steppe vegetation of periglacial areas was replaced by birch forest-tundra with shrub under storey, and the thawing and lowering of permafrost started to spread quickly (Blyakharchuk and Sulerzhitsky, 1999). The further warming of climate promoted the spread of spruce along the river valleys and lowlands. Climatic conditions became much warmer than in late-glacial time but did not reach the present level.

In the second half of the Preboreal (PB) the climatic conditions became drier as a result of further warming. That was favorable for the spread of birch forest-steppe in the area of modern forest zone (Volkova and Levina, 1985; Koshkarov, 1998; Blyakharchuk and Sulerzhitsky, 1999). At the same time in foreststeppe zone humidity increased during second half of preboreal. Some authors mention the cooling of climate during this time (Khotinskiy, 1977), but the spread of such a thermophylous tree like Abies sibirica Ledeb. (Blyakharchuk and Sulerzhitsky, 1999) and thermophylous water plants (P'yavchenko, 1983; Koshkarov, 1998) does not agree with this conclusion. About $9500 \mathrm{yr}$ BP the forest plant communities existed in a zone of modern tundra on Cape Karginsky (Firsov et al., 1974). Just as at the beginning of the Holocene in the Yenisei River area, part of the forest zone of Western Siberia show changes from foreststeppe to birch forest and then to dark coniferous forest of the modern taiga (Koshkarova,1989; Koshkarov,1998). By the opinion of these authors the decreasing continentality of the climate and the increasing moisture caused these change in forest-steppe zone.

Boreal period (BO). The next remarkable warming of climate took place in the Boreal period 8300-8500 yr BP. Precipitation increased (Khotinskiy,1984), promoting the widespread expansion of spruce throughout the vast territory of Western Siberia. Some scientists consider that the climate of Western Siberia in Boreal time was cooler than today and that the steppe zone was shifted to the south and situated out of Western Siberia (Volkova and Levina, 1985). Other investigators show that average temperatures in January and annual precipitation were higher than modern north of 60 degrees $\mathrm{N}$, and the opposite to the south (Velichko et al., 1997; Savina and Khotinskiy, 1984). At the same time the average July temperatures were lower than modern north of 60 degrees N. According to V.L. Koshkarova (1989) and A.D. Koshkarov (1998) during the Boreal warming the climate was warmer and drier than modern in the southern taiga zone in the Yenisey River area. The amount of precipitation was 40-50 mm less, and latitudinal zones were shifted to the north by 4-5 degrees from the modern position. Forests expanded in the tundra zone (Levkovskaya et al., 1970). In the modern taiga zone the larchspruce forests spread together with birch foreststeppe (Blyakharchuk and Sulerzhitsky, 1999). Accordingly palaeoclimatic curve of southern type (Fig. 1, D) reflects mostly drier climate during $\mathrm{BO}$ with short increase of humidity 
in the middle of $\mathrm{BO}$ and more wet climate in taiga zone (Fig. 1, A, and G). The process of podsolization was interrupted by formation of steppe soils in the zone of the modern southern taiga (Koshkarov, 1998). The type of latitudinal zonation in the Boreal was rather different from modern.

Atlantic period(AT). The climatic optimum of the Holocene is best expressed in Western Siberia at 5500-6000 yr BP. Most investigators consider that during this time the climate was warmer and wetter than modern in the forest zone. It caused the new expansion of forests into the tundra zone on Cape Karginsky (Firsov et al.., 1974; Levkovskaya et al.., 1970) and the spread of lime, oak, and elm in the western part of the forest zone of Western Siberia (Volkova and Levina, 1982). At the opinion of N.A. Khotinskiy (1984) the southern boundary of the forest zone in Western Siberia was stable in the second half of the Holocene. But later there were found quite a lot of evidences, that the southern boundary of the forest zone was considerably shifted to the north in the Atlantic climatic optimum, as indicated by the formation of a second humus horizon in the relic soils of the modern southern taiga (Orlova and Panychev, 1989). In the steppe zone the great decrease in the size of Lake Chany as a result of drying was dated as $5530 \mathrm{yr} \mathrm{BP}$ (Orlova, 1986), and steppe communities spread into the forest-steppe zone. Peat accumulation started on some dried lakes in the forest-steppe zone at this time. Moreover it was proved, that there were numerous less profound movements of southern boundary of forest zone in Western Siberia caused by climatic fluctuations (Levina and Orlova, 1993). The deviations of climatic parameters from modern values in the Holocene optimum changed in accordance with latitude. Thus in the forest zone the annual temperatures exceeded modern by 1-1.5 degrees, and the precipitation were $25-50 \mathrm{~mm}$ greater. These conditions promoted widespread Abies forests in Western Siberia, which expanded to the north of the modern position by $200-300 \mathrm{~km}$ (Glebov et al., 1996; Blyakharchuk and Sulerzhitsky, 1999; Koshkarov, 1998). According to other scientists (Volkova and Levina, 1985) the climate of the Holocene optimum was 3.5 degrees warmer than modern, and latitudinal zones were shifted $500-600 \mathrm{~km}$ north of their modern positions. The average January temperature in the modern forest-tundra zone was increased 5-6 degrees (Burashnicova et al., 1982; Khotinskiy, 1984). Another opinion is that the expansion of forests to the north was caused not by warming of the climate, but by the increase of continentality (Danilov, 1989). The author considers, that in more continental climate due to more hot summers the permafrost in soil thawed deeper and it was favourable for grows of trees. According to A.A.Velichko (1989), in the Holocene optimum the increase of average global temperature at high latitudes was maximal in winter $(+4$ degrees), whereas in the south the positive deviations decreased, and at 40-50 degrees $\mathrm{N}$ mostly cooling took place. Precipitation increase was the same in high and low latitudes. In the middle areas (steppe zone of Western Siberia) precipitation was less than modern. At the same time palaeoclimatic curves constructed by T.P.Levina and L.A Orlova (1993) do not show pronounced warming in forest-steppe zone, but rather more stable steppe conditions compare with previous and next Holocene periods (Fig. 1, D). On the contrary, palaeoclimatic curves from forest zone demonstrate more warm climate with cooling in the middle AT and other smaller fluctuations of temperature and humidity (Fig. 1, $A, B$ and $G)$.

Subboreal period (SA). The climate of the Subboreal period was unstable, but mostly cooler than that in the Atlantic in the forest and forest-tundra and forest-steppe zones. The 
northern boundary of the forest zone retreated to the south by almost 2 degrees. Most scientists consider $4500 \mathrm{yr}$ BP as a time of dry cooling in the late Holocene (Blyakharchuk, 1989; Volkova and Levina, 1985; Koshkarov, 1989; Khotinskiy, 1984). But in the opinion of F.Z. Glebov et al., (1996) the dry warming of the Subboreal allowed cotton-grass peat to form on the mires of Western Siberia. In any case it was a dry period, as indicated by the renewed regression of lakes in the steppe and forest-steppe (Orlova, 1986). After the dry period the climate became wet and cool, causing the afforestation of foreststeppe and partly of the steppe zone. The cooling at $4300 \mathrm{BP}$ stimulated the freezing of some wet mires in the middle taiga zone and formation of palsa bogs in the northern taiga and forest-tundra (Blyakharchuk and Sulerzhitsky, 1999; Peteet et al., 1998). Relatively thermophyllous Abies forests retreated to the south to the position of the modern southern taiga. The widespread expansion of siberian pine ( Pinus sibirica) started. In central areas of Western Siberia in the second half of the Holocene the continentality increased. This fact supports the model of Siberian continental type of climatic changes (Khotinskiy,1984). Fluctuations of climate to more cool and dry conditions are expressed in palaeoclimatic curves for forest zone (Fig. 1, A, B, F and G, H) and to more unstable conditions in curve for forest-steppe (Fig. 1, D).

Subatlantic period (SB). During subatlantic time the cold phases took place at 2800, 1700 and $500 \mathrm{yr}$ BP (Levina and Orlova, 1993). The following dry events at 2500-3000, 1500, and $600-800$ yr BP were marked by afforestation of mires in the southern taiga zone and by regressions of lakes in the forest-steppe and steppe (Blyakharchuk, 1989; Orlova, 1986; Levina and Orlova, 1993). At the opinion of N. A. Khotinskiy (1989) the century oscillations of climate during last millennium had the tendency that warming in humid areas coincided with stages of aridification in the steppe zone, and cooling in humid areas coincided with wetter conditions in arid zones.

\section{Conclusion}

Correlation of palaeoclimatic curves of temperature and humidity (which have been constructed with use of different methods on the base of pollen, macrofossil and radiocarbon data) demonstrated complicated pattern of climatic changes in Western Siberia during the Holocene. Complexity is expressed both in space and in time scales. But never the less there are common features in different palaeoclimatic curves, which are caused by global, possibly, solar-orbital driving forcing of climatic changes in Western Siberia. On this pattern a smaller oscillations are superimposed, possibly induced by changes of local climates. The last were caused by the rearrangement of atmospheric circulation above Western Siberia and by peculiarities of local environment in each study site. For more correct modeling of past and future climatic changes in such vast and diverse area like Western Siberia, which could include not only time palaeoreconstructions, but also space-time models, there is obvious need in an accumulation of more sites supplied by detailed palaeoecological data of high scientific level accepted on modern palaeogeographic research. And in each separate case a special attention should be paid to complex local conditions in affecting pollen and other palaeo proxy data so to avoid mix of local and regional signals. Correlation of different proxies on one time scale is a good instrument for this aim.

\section{Acknowledgments}

The author thanks Professor Dr Herbert E.Wright (University of Minnesota, USA) for advices and linguistic improvements of this entry. The work was performed under support of grants of RFBR № 05-05-64266 and № 06-05-65127. 


\section{References}

Blyakharchuk T.A. (1989) History of vegetation and climate of south-east of Western Siberia in the Holocene (according to macrofossil and spore-pollen analyses of peat deposits). Dissertation of candidat of biological sciences. Tomsk, 226 p.(in Russian)

Burashnikova T.A., Muratova M.V., Suetova I.A. (1982) Climatic model of territory of Soviet

Union during The Holocene optimum. In: A.A. Velichko (ed.) Development of nature of USSR in the late Pleistocene and the Holocene. Nauka, Moscow, p.245-251. (in Russian)

Velichko A.A. (1989) The Holocene like element of global natural processes. In: A.A. Velicko (ed.) Palaeoclimates of the late Glacial and the Holocene. Nauka, Moscow, p. 2-12. (in Russian)

Volkova V.S. and Levina T.P. (1985) The Holocene like model for investigation of interglacial epoch of Western Siberia. In: A.F. Khlonov (ed.) Palynostratigraphy of the Mesozoic and Cenozoic of Siberia. Nauka, Novosibirsk, p. 74-84. (in Russian)

Volkova V.S. and Klimanov V.A. (1988) Palynology and climate of Western Siberia during main thermal maximums of the Holocene (8500, 5500, 3500 yr. BP). In: S.B. Shatski (ed.) Microfissils and stratigraphy of Mesozoic and Cenozoic of Siberia. Nauka, Novisibirsk, p. 91-99. ((in Russian)

Glebov F.Z., Karpenko L.V., Klimanov V.A. and Mindeeva T.N. (1996) Palaeoecological analysis of peat section in Ob'-Vasyugan inter fluver area. Siberian ecological Journal 6: 497-504. (in Russian)

Danilov I.D. (1989) Palaeoclimates of the late Pleistocene and the Holocene of the north of Siberia in Cenozoic time. In: V.S. Zykina (ed.) Cenozoic of Siberia and Far East of USSR. Nauka, Moscow, p.167-172. (in Russian)

Zubareva G.Yu. (1987) Change of palaeoclimate of south-Minusinsk hollow in the late Holocene. In: A.F. Yamskikh (ed.) Palaeogeography of the Central Siberia. Krasnoyarsk pedagogical institute Press, Krasnoyarsk, p. 41-64. (in Russian)

Klimanov V.A. (1976) To the method of reconstruction of quantitative parameters of past climate. Vestnik MGU, ser. Geography, 2: 92-98. (in Russian)

Klimanov V.A. and Sirin A.A. (1997) Dynamics of peat accumulation in northern Asia during last 3000 years. Doklady Akademii Nauk, V.354, 5: 683-686. (in Russian)

Koshkarov A.D. (1998) Palaeoecology of dynamic of forest and mire systems and climate of the area Kass River in the late Pleistocene and the Holocene. Thesis of candidat of boil. sciences, Krasnoyarsk, 25 p. (in Russian)

Koshkarova B.L. (1989) Holocene climatic changes in the area of Yenisei River (according to palaeoecological data). In: N.A.Khotinskiy (ed.) Palaeoclimates of the late Glacial and the Holocene. Nauka, Moscow, p.96-98. (in Russian)

Levina T.P. and Orlova L.A. (1993) The Holocene climatic cycles in the south of Western Siberia. Geology and geophysics 3: 38-55. (in Russian)

Levkovskaya G.M., Kind N.V., Zavelski F.S. and Firsov V.S. (1970) Absolute chronology of peat deposits in the area of Igarka and partition of the Holocene in Western Siberia. Bulletin of commission for investigation of the Quaternary period 39: 94-101. (in Russian)

Orlova L.A. (1996) Stratigraphy and radiocarbon chronology of the Holocene of southern Siberia (example from Barabinskaya forest-steppe and Novosibirsk Priob'e). Autoref. diss. cand. geol.-mineral. Sciences. Novosibirsk, 16 p. (in Russian) 
Orlova L.A. and Panychev V.A. (1989) Radiocarbon dating of podzolic soils with second humus horizon. In: Regional stratigraphy of Siberia and Far East. Nauka, Novosibirsk, p.125-135. (in Russian)

P'yavchenko N.I. (1983) About age of peat deposits and Holocene change of vegetation in the south of Western Siberia. Bulletin commission for investigation of the Quaternary period 52: 164-170. (in Russian)

Savina S.S. and Khotinski N.A. (1982) Zonal method of reconstruction of palaeoclimates of the Holocene. In: A.A.Velichko (ed.) development of nature on the territory of USSR in the late Pleistocene and the Holocene. Nauka, Moscow, p.179-186. (in Russian)

Trifonova L.I. (1982) Peculiarities of atmospheric circulation. In: Climate of Tomsk. Gidrometeoizdat, Leningrad, 176 p. (in Russian)

Firsov L.V., Troitski S.L., Levina T.P., Nikitin V.P. and Panychev V.P. (1974) Absolute age and first standard pollen diagram of Holocene peat section in northern Siberia. Bulletin of commission for investigation of quaternary period 41: 121-127. (in Russian)

Khotinskiy N.A. (1977) The Holocene of northern Eurasia. Nauka, Moscow, 200 p. (in Russian)

Khotinskiy N.A. (1989) Disputable questions of reconstruction and correlation of palaeoclimates of the Holocene. In: N.A. Khotinskyi (ed.) Palaeoclimates of the late Glacial and the Holocene. Nauka, Moscow, p. 12-17. (in Russian)

Shnytnukov A.V. (1951) Variability of solar radiation during historical epoch on the base of it's Earth's manifestations. Bulletin of commission for investigation of Sun 7 (21): 47-70. (in Russian)

Shumiliva L.V. (1962) Botanical geography of Siberia. Tomsk University Press, Tomsk, 439 p. (in Russian).

Blyakharchuk, T.A. \& Sulerzhitsky, L.D. (1999) Holocene vegetation and climatic change in the forest zone of Western Siberia according to pollen records from the extrazonal palsa bog Bugristoe. The Holocene 9,5: 621-628.

Khotinskiy, N.A. (1984) Holocene vegetation History. In: A.A.Velichko, H.E.Wright, Jr., \& C.W. Barnosky (eds.). Late Quaternary Environments of the Soviet Union. University of Minnesota Press, Minneapolis, p. 179-200.

Mangerud, J., Andersen, S.T., Berglund, B.E. \& Donner, J.J. (1974) Quaternary stratigraphy of Norden, a proposal for terminology and classification. Boreas 3: 109-128.

Peteet, D., Andreev,A., Bardeen,W. \& Mistretta, F. (1998) Long-term Arctic peatland dynamics, vegetation, and climatic history of the Pur-Taz regions, Western Siberia. Boreas 27: 115-26.

Savina, S.S. \& Khotinskiy (1984) Holocene palaeoclimatic reconstructions based on the Zonal Method // Late Quaternary environments of the Soviet Union. In: A.A.Velichko, H.E.Wright, Jr., and C.W. Barnosky (eds.). Late Quaternary Environments of the Soviet Union. University of Minnesota Press, Minneapolis, p. 287-296.

Velichko, A.A., Andreev, A.A. \& Klimanov, V.A. (1997) Climate and vegetation dynamics in the tundra and forest zone during the Late Glacial and Holocene. Quaternary International 41/42: 71-96. 